\title{
REALITIES OF PRACTICAL ANDRAGOGY IN THE CONDITION OF THE COVID-19 PANDEMIC: MIGRATION PEDAGOGY IN UKRAINE
}

\author{
I. Deineha, L. Hromozdova, V. Kovach
}

\begin{abstract}
The purpose of this article is to make recommendations for the organization of adult education in quarantine conditions: exchange of experience.

The article identifies that "Lifelong Learning" is one of the priorities of society in all countries, focusing on such potentials of andragogy as promoting the social adaptation of adults and addressing issues of labor migration. In the conditions of COVID-19, an effective form of work was interactive communication through e-mail, work in Viber-groups and the use of the electronic platform ZOOM for distance lectures. It has been proven, that the methods of work of a teacher and an andragogue are not identical: adult learners and full-time university students are different mental subjects of education. The theory and methodology of teaching economic disciplines in these two varieties are very different. The authors present the results of the analysis of modern scientific sources, which testify in favor of the need for further development of andragogical learning technologies. The experiment of this study and comparative analysis was not planned, it took place for objective reasons, caused by the COVID-19 pandemic. The obtained results in practical andragogy are useful for teachers-practitioners, andragogues, employment services - especially in cases of force majeure in adult education (COVID and others) and for quality administrative control over the learning process in extreme conditions or at a distance operating mode
\end{abstract}

Keywords: andragogy, lifelong learning, migration pedagogy, COVID pandemic, electronic diary

Copyright (C) 2020, I. Deineha, L. Hromozdova, V. Kovach. This is an open access article under the CC BY license (http://creativecommons.org/licenses/by/4.0).

\section{Introduction}

Due to growing tendencies of demographic ageing [1], education for adults becomes a traditional phenomenon. Growing tendencies of its development as folk education are observed in societies of practically all countries of the world [2], including Ukraine [3]. Andragogy implements new learning technologies for adults, changes in its theoretical-methodical basis take place $[4,5]$.

Since the end of 2014 the word combination "migration pedagogy" became to circulate in the business scientific pedagogical vocabulary in Ukraine. Military actions in the territory of Donetsk and Lugansk regions generated the wide flow of migrants in central and western regions of Ukraine.

In that time scientific institutions on retraining and qualification improvement together with employment services started the active work for adaptation of temporally replaced persons to regional labor markets.

The learning-scientific institute of continuous education (LSICE), created on the base of the National aviation university (NAU) in Kyiv city, retrained the staff from students, directed for studying by the employment service, including persons, replaced from the Eastern regions, who are temporally unemployed at the labor market and need qualified adaptation for its demand, for many years.

The conference "Lifelong learning: social demands, modern challenges and priorities in realization" that took place at the National aviation university in Kyiv city at 22 of March of 2018, and the expert convent
"Lifelong learning", that took place in LSICE NAU at 20 of March of 2019, determined working priorities as to civilization challenges of education for adults [3, 5]. Among them: solving problems of the labor migration staff, social integration of temporally replaced persons, education for advance, for training scientific and managerial staff, andragogic business-education, formation of basic competences in the sphere of continuous education, ecologization of education, reformation of the system of postgraduate education, synergetics of education for sustainable development, specificity of migration education and so on [6].

The COVID-19 pandemic, total quarantine added many new problems to education for adults, namely: immediate adaptation of theoretical and methodological principles to activities under COVID-19 quarantine conditions. Changes were also needed in the work with students of the third generation, including internal migrants. Having been formed on the base of LSICE NAU in 2018 as an analogue to Sweden folk education, it functions effectively till now and strives answering all questions, interesting or useful for its students [2].

The problem of finishing the learning year under conditions of the COVID pandemic has been solved with the great intensity of teachers' work and difficulties. According to prognoses, the next learning year will also need the same theoretical and methodological approaches, used under extreme conditions of the first wave. That is why the research, given in this paper, is topical. 
The scientific novelty of the paper is in presenting results of the empirical study of practical andragogy under conditions of the COVID-19 quarantine (on the example of LSICE NAU in Kyiv city).

\section{Literary review}

Among original ideas, highlighted in modern scientific editions, we can see the experience of folk education, developed in Scandinavia, countries of the European Union, Canada, USA, countries of Eastern partnership that appreciate creativity and development of creative abilities of third generation people, their informal education, studied by N.P. Pavlik (2016) [2], where social involvement of elderly takes place with an effective mechanism of public financing of adult education, studied by T. Grishyna (2015) [3]. Modern science proposes methods of creation of intellectual adaptive learning systems for adults, new learning methods for them that mostly increase their motivation to learning, provide a problemreflection approach, favor overcoming of negative social tendencies, including migration phenomena. This is presented in studies by L. Nikolenko, V. Burenko, O. Dubasyuk, T. Desyaty [4, 7]. The essence of the phenomenon "continuous lifelong learning" is comprehensively analyzed by L. B. Lukyanova [8, 9], the author proved that continuous education is not a new phenomenon in history, views of the famous European scientists: P. Alhait, E. Gruber, Y. Knol, K. Houl, Z. Nold, V. Lenz, P. Faultish on the role of lifelong learning were analyzed. Based on generalization of researchers on this problem, the author has separated four development periods of lifelong learning: ascertaining-identifying, methodological, theoretical expansion, activity-value that is very important contribution in the andragogy theory [8]. Interesting and substantiated ideas are offered by young Ukrainian scientists, among which is Ruslana Presner (2016) [5]. Studies are continued that proves the development objectivity of education for adults, that is "ageing" of the population of the planet and great migration flows because of military events and disasters.

\section{Aim and tasks of research}

The aim of this paper is to elaborate recommendations as to organizing education for adults under quarantine conditions as experience exchange. The following tasks were set for attaining the aim:

- to generalize the experience of practical andragogy of the Learning-scientific institute of continuous education of the National aviation university (LSICE NAU) in Kyiv city in the period of the first wave of the COVID-19 pandemic in Ukraine;

- to determine effective forms of distant learning in migration pedagogy, system of staff retraining (on the example of the work of LSICE NAU in Kyiv city);

- to elaborate methodical recommendations on conducting distant activities with an adult audience, based on migration pedagogy;

- to offer methods of administrative control on activities quality and volumes of passed programs of the studied course.

\section{Methods and materials of research}

For studying the organization system of education for adults for preventing negative results of labor migration, the following materials were used:

- e-materials of correspondence between a teacher and an audience in the period of distant activities at COVID-19;

- methodical support of the course of external economic activity management;

- informational platform by The Ownes.

Research methods were: comparison method for comparing the effectiveness of distant learning technologies for educational subjects of different mentality; system analysis method - for estimating development tendencies of education for adults in Ukraine; einterview method - for efficient interrogation of needs of the audience.

\section{Research results and their discussion}

For realizing the state program of creation of new working places and prevention of negative results of labor migration, courses for staff training in external economic activity management on the base of higher economic education function for three years in the LSICE NAU. Progressive andragogic technologies are used in the process of training managers of external economic activity [5]. The thematic curriculum of the learning discipline "External economic activity management" covers the wide spectrum of economic themes, which studying forms in students necessary competences for working in the sphere of external economic activity or scientific one [7]. Among main topics, favoring formation of these competences there are:

1. Theoretical bases of external economic activity management.

2. International companies as integrated corporative structures.

3. Transnational corporations.

4. State regulation of external economic activity.

5. International trade. World market structure.

6. International agreement.

7. Incoterms - international trade rules.

8. Entrepreneurship in the sphere of external economic activity and so on.

Traditional education for adults is realized by this curriculum for retraining the staff and forming the balanced labor market, taking into account labor migration from the Eastern regions of Ukraine.

Such group started according to the curriculum of staff retraining in LSICE NAU since 12 of March of 2019. The quarantine because of the COVID pandemic, proclaimed at 12 of March of 2020, made all these working forms impossible.

An extreme situation, destructing plans of students for getting the prestigious specialty and then - carrier growth and material welfare, formed. It was improved by all possible methods.

The first attempt with hopes that the quarantine must be short (prognosed - till 4.04.2020) was made to direct the whole methodical web-arsenal, developed by teachers for passing the course under in-class conditions, on independent acquaintance at home. E-variants of text- 
books, presentations of separate topics and lectures were sent to students for independent learning. In the first week after proclaiming the quarantine, panic and confusion of the audience were felt in feedback.

Appeals for help were sent to teachers' e-mail. We cite the real material of the first days of distant learning, organized as independent acquaintance with materials, given by teachers. The students' reaction is illustrated by their e-mails to teachers, namely (in March of 2020 - first quarantine days):

- at conducting lectures in the ordinary mode, the course structure would be automatically constructed for students. But for this moment, without a distinct curriculum, without recommendations from You-teachers, the process is in chaos;

- in the aspect of learning management, we extremely need a distinct plan of actions;

- organization of activities is needed;

- management theory is good, but practical skills are necessary, especially in working with documents on international agreements: CMR, custom declarations, revelation of mistakes in documents, making EEA agreements using Incoterms and ISO rules and so on. There are students, who accent attention on the fact that at passing interviews, they were just given such documents for comments, and their analytic abilities were assessed by these comments;

- we understand that this whole situation is an incredible challenge for You, dear teachers. But help us, please, if it is possible!

This was a reaction to the first week of learning in the distant mode. At that the group was given with:

- the EEAM curriculum;

- the list of literature on the discipline "External economic activity management", 11 sources;

- the e-textbook "External trade operations: theory and practical tasks";

- tests for checking knowledge;

- presentations, discovering topics of the EEAM course, including: "International economic activity and international economic relations", "European integration", "Treaty interrelations and partner connections".

For comparing, we can ascertain, based on own experience: HEI students of the day learning form cope with such load volumes easily. The cause is different mentalities of day students and ones of the adult learning system [5]. The last ones appreciate time greatly, have extreme limitations in it because of family duties, work at summers cottages, kitchen gardens, farms of parents in rural areas, and in cases of temporally replaced persons partial employment. Most day students focus only on learning, their life is only education.

The administration, worked distantly because of the COVID quarantine, faced questions about organization of forms of control over passing distant activities, volumes of presented material, and most important over realization of course programs.

The solution was e-means of fixing information that fix facts and content of interactive communication between the teacher and the audience. One of fixation forms of such information with further expert assessment of knowledge presentation quality in LSICE NAU be- came an e-diary of interactive communication between the teacher and the audience.

As an experience exchange, we offer colleagues' attention several e-pages of the diary of interactive communication of students of the course "External economic activity management" at the COVID-19 pandemic.

1.04.20 Attention, students of the EEAM group! From the teacher of EEAM

Get information about online activities by The Ownes Talk in April of 2020. Pay attention to the topics:

3.04.20 How to provide safety and to protect yourself and your business at quarantine.

6.04.20 How to earn in start-ups and to be attractive for investors under crisis conditions.

10.04.20 Export of Ukrainian production

12.04.20 For attention of students of the EEAM group! From the teacher of EEAM

At studying the topic "Incoterms - international trade rules" version 2000 is not acceptable.

For an interview you must know version 2010 and changes, introduced in these rules since January of 2020

EMPLOYERS PAY ATTENTION TO THESE QUESTIONS.

Another important topic - Agreements (Contracts) of EEA. Analogically.

13.0420 For attention of students of the EEAM group! From the teacher of EEAM

For today there are several variants of Incoterms 2020. There is a difference from incoterms-2010 by four rules. By one term only: DAT is replaced by DPU. Discussion is continuing now. Popular information and data about the work of The International chamber of commerce for elaborating Incoterms can be read at www. golovbukh.ua

15.04.20 For attention of students of the EEAM group! From the teacher of EEAM

Continue the answer for point 3 from the course leader's letter.

What must be known about Incoterms-20 at an interview with an employer?

Incoterms (International commerce terms) are international rules as to interpretation of terms (it's better to say word combinations of 3 key words, written in English) in the sphere of international trade.

These rules were first elaborated by the International chamber of commerce in 1921. Then changes were in: $1953,1967,1976,1980,1990,2000,2010,2020$. In present times it is accepted to introduce changes each 10 years, if another is not really required. Version 2020 still discussed for today.

These rules determine conditions of commodity supply and are obligatory given in an Agreement (Contract). It is accepted to use not a complete word combination, but only its abbreviation (three English letters). For example, EXW, CPT and other.

In practice just these abbreviations are called rules. They are accepted by governments of all countries, juridical firms and commercial structures, businessmen of all world countries. They are obligatory for use by exporters, importers, carriers and insurance firms.

Rights and duties of sides of a trade contract as to commodity supply are coded in these abbreviations. The 
term "franco" (in translation) means a place of responsibility, transferring from a buyer to a seller. In the figure, presented below, a light line means seller's responsibility; dark line - buyer's responsibility.

11 rules (abbreviations) are included in the last versions of 2010 and 2020.

Incoterms version 2010: The first class includes seven rules of INCOTERMS-2010, may be used despite a chosen transport and its number. This class includes the following terms: EXW, FCA, CPT, CIP, DAT, DAP, and DDP.

Port is a supply point and place, to which commodities are supplied for a buyer in the second class of rules Incoterms-2010, that is why this class is called: For marine and internal water transport. The following terms relate to it: FAS, FOB, CFR and CIF.

Incoterms version-2020: The first class includes seven rules of INCOTERMS-2020, may be used despite a chosen transport and its number. This class includes the following terms: EXW, FCA, CPT, CIP, DAP, DPU i DDP.

Port is a supply point and place, to which commodities are supplied for a buyer in the second class of rules Incoterms-2010, that is why this class is called: For marine and internal water transport. The following terms relate to it: FAS, FOB, CFR and CIF.

11 terms (abbreviations) are included in Incoterms2010 as in Incoterms-2020, 7 of them are universal - for any transport; 4- for marine and internal water one.

Rules are divided in two classes in Incoterms2020: 7 and 4 rules.

The main difference of Incotems version - 2020 from Incoterms version -2010:

The rule "Delivery at a terminal" (DAT) that works in Incoterms version- 2010 was replaced in Incoterms version-2020 for "Delivery at a place of unload" for explaining that any place may be one of destination, not only "terminal".

Incoterms - 2020 puts more responsibility for safety and additional costs on a seller.

The content of abbreviations must be investigated in the process of contract preparation.

Incoterms-10 is needed at working with existing contracts, Incoterms-20 is needed at making (remaking) new contracts.

(Then Internet-materials are offered to students for detail study).

20.04.20 From the teacher of EEAM. To students of the EEAM group: I recommend:

24.04.20 at 15-00 to watch TV-program "Evening at the eighth" with participation of Oksana Skan on organization of the effective documents circulation of EEA firms and questions of tax planning in different world countries.

30.04.20 From the teacher of EEAM. To students of EEAM group 1.

Our course is at the final stage. Unfortunately, inclass learning is still impossible. So, let's use all possibilities of distant learning, including ZOOM service.

I give you the following information: for several years students of EEAM courses have been constant participants of scientific seminars of "The OWNES consulting» that work for today in Ukraine in the distant mode by online platforms, created by the support of EBRD within the EU initiative.

For presenting the content of the program on EEA management, the online-conference of actual experience of international marketers, namely: business-cases as to adaptation to new conditions is available.

5 of May 2020 at 15-00 ... On important decisions of internal work of a company under crisis conditions.

7 of May of 2020 at 15-00 Marketing and sales. How to prevent a profit decrease, to find new clients.

8 of May of 2020 at 11-00 Financial management. Optimization of finances of enterprises of small and middle business.

8 of May of 2020 at 15-00 Automation (digitalization) of business-projects.

These lectures present participants a block of questions, provided at the day learning form, namely:

- making managerial decisions at EEA enterprises;

- international marketing as an EEA component;

- financial accounting in management of an enterprise.

The registration mode and the time table of online-lectures will be given to you by the course leader.

Authors' note: selective materials from pages of the e-diary were presented above.

Despite its practical easiness, just the method of ediary turned to be high-effective. Its advantages - communication easiness, it doesn't need an additional training, cheapness, it can be used at any time, comfort for both parties of the dialogue, mobile, easily sent to all interested parties.

The transfer to using conference-means and reflecting information at the interactive table of the ZOOM platform became revolutionary for overcoming a deficit of communication with the teacher under conditions of the COVID-19 quarantine. Online lectures became possible due to the ZOOM platform.

We offer to colleagues an example of ZOOMlecture formation in these methodical recommendations.

TOPIC "Making managerial decisions at enterprises based on incremental and marginal analysis"

Algorithm of studying the topic:

1. Main categories of the topic: increment, marginal limit, profit maximization conditions.

2. Acquaintance with presentations, given by the teacher - theory of the question.

3. Filling of calculating table 1 , sent by e-mail to each lecture participant 4 days before the lecture beginning for making calculations and revealing negative profit zones.

4. Revelation of the optimal production volume (situation of maximal profit).

\section{Point 1 of the algorithm}

Theoretical bases that must be known:

Management is a purposeful action, it is a vector by mathematical logic, in practice it is decision making.

Analysis is disintegration in components, separate sections of economic activity (in practice it is usually tables). It must be kept in mind, that a final accord of an analysis is a synthesis of obtained results: an integral decision forms just by this way.

Increment - a growth of a product. (In mathematics growth is denoted as "delta"). 
Marginal (extreme) limit - an expedient production volume, where the profit is maximal (if made by 1 unit more - the profit falls, if made by 1 unit less - the maximal profit is not reached).

Profit - a difference between price (profit from realization) and prime cost (costs for production).

Condition of firm profit maximization: $\mathbf{I R}=\mathbf{I C}$ (or $\mathrm{MR}=\mathrm{MC})$, where IR - increment of receipts from realization of the next unit of a product
(MR extreme value of IR) IC - increment of costs for production of the next unit of a product (MC - extreme value of IC)

\section{Point 2 of the algorithm}

1. Read the presentation independently. Questions in ZOOM: conference identifier 74196305151 password 4iAWBS (time will be informed by the course leader)

2. Table1 - with the data for calculation is added. Point 3 of the algorithm.

Table 1

Management of an EEA enterprise, based on incremental and marginal analysis

\begin{tabular}{|c|c|c|c|c|c|c|}
\hline $\mathrm{Q}$ & $\mathrm{AC}$ & $\mathrm{TC}$ & IC(including MC) & $\mathrm{P}$ & TR & IR(including MR) \\
\hline $\begin{array}{l}\text { Quantity of pro- } \\
\text { duced commodi- } \\
\text { ty units }\end{array}$ & $\begin{array}{l}\text { Average } \\
\text { costs }\end{array}$ & Total costs & $\begin{array}{l}\text { Incremental (includ- } \\
\text { ing marginal) costs }\end{array}$ & Price & $\begin{array}{l}\text { Total in- } \\
\text { come }\end{array}$ & $\begin{array}{l}\text { Incremental (includ- } \\
\text { ing marginal) in- } \\
\text { come }\end{array}$ \\
\hline 1 & & 24 & - & 41 & 41 & - \\
\hline 2 & $43.5 / 2=$ & 43,5 & 19.5 & 39 & $78=(39 * 2)$ & 37 \\
\hline 3 & & 59,25 & $15.75=(59.25-43.5)$ & 37 & 111 & $33=(111-78)$ \\
\hline 4 & & 72 & & 35 & & \\
\hline 5 & & 82.5 & & 33 & & \\
\hline 6 & & 91.5 & & 31 & & \\
\hline 7 & & 99.75 & & 29 & & \\
\hline 8 & & 108 & & 27 & & \\
\hline 9 & & 117 & & 25 & & \\
\hline 10 & & 127.5 & & 23 & & \\
\hline 11 & & 140.25 & & 21 & & \\
\hline 12 & & 156 & & 19 & & \\
\hline 13 & & 175.5 & & 17 & & \\
\hline 14 & & 199.5 & & 15 & & \\
\hline 15 & & 228.25 & & 13 & & \\
\hline 16 & & 264 & & 11 & & \\
\hline 17 & & 306 & & 9 & & \\
\hline
\end{tabular}

Task: To finish the table calculation by the example, to make the incremental and marginal analysis and to make a conclusion - which volume of a product must be produced by the firm for getting the maximal profit.

Point 4 of the algorithm

Table 2

Management of an EEA enterprise, based on incremental and marginal analysis

\begin{tabular}{|c|c|c|c|c|c|c|}
\hline $\mathrm{Q}$ & $\mathrm{AC}$ & $\mathrm{TC}$ & $\mathrm{IC}($ including MC) & $\mathrm{P}$ & $\mathrm{TR}$ & IR(including MR) \\
\hline $\begin{array}{c}\text { Quantity of pro- } \\
\text { duced commodi- } \\
\text { ty units }\end{array}$ & $\begin{array}{c}\text { Average } \\
\text { costs TC/Q }\end{array}$ & Total costs & $\begin{array}{c}\text { Incremental (in- } \\
\text { cluding marginal) } \\
\text { costs }\end{array}$ & $\begin{array}{c}\text { Price } \\
\text { come } \\
\mathrm{P}^{*} \mathrm{Q}\end{array}$ & $\begin{array}{c}\text { Incremental (in- } \\
\text { cluding marginal) } \\
\text { income }\end{array}$ \\
\hline 1 & 24 & 24 & - & 41 & 41 & - \\
\hline 2 & 21.75 & 43.5 & 19.5 & 39 & 78 & 37 \\
\hline 3 & 59.25 & 59.25 & 15.75 & 37 & 111 & 33 \\
\hline 4 & 72 & 72 & 12.75 & 35 & 140 & 29 \\
\hline 5 & 82.5 & 82.5 & 10.5 & 33 & 165 & 25 \\
\hline 6 & 91.5 & 91.5 & 9 & 31 & 186 & 46 \\
\hline 7 & 99.75 & 99.75 & 8.25 & 29 & 203 & 17 \\
\hline 8 & 108 & 108 & 8.25 & 27 & 216 & 13 \\
\hline 9 & 117 & 117 & 9 & 25 & 225 & 9 \\
\hline 10 & 127.5 & 127.5 & 10.5 & 23 & 230 & 5 \\
\hline 11 & 140.25 & 140.25 & 12.75 & 21 & 231 & 1 \\
\hline 12 & 156 & 156 & 15.75 & 19 & 228 & -3 \\
\hline 13 & 175.5 & 175.5 & 19.5 & 17 & 221 & -7 \\
\hline 14 & 199.5 & 199.5 & 24 & 15 & 210 & -11 \\
\hline 15 & 228.25 & 228.25 & 28.75 & 13 & 195 & -15 \\
\hline 16 & 264 & 264 & 35.75 & 11 & 176 & 19 \\
\hline 17 & 306 & 306 & 42 & 9 & 153 & -23 \\
\hline
\end{tabular}


The teacher's comment:

Additional costs for each additional next unit of a product is called an incremental value, or, as mathematicians say, augmentation. Analogously, an additional income from realization of each next unit of a product is called incremental (or augmentation).

Marginal or extreme (MC) and (MR) in both columns are values $M C=9$ and $M R=9$ that correspond to the maximum of profit that in the language of graphic illustration means the most deviation of graphs of two parabolas (MC) - cubic and (MR) - negative square. On Fig. 1 this deviation is reached by the point that corresponds to production volume 9 (it must be noted, that in this case the numerical coincidence of the value $\mathrm{Q}=9$ with $\mathrm{MC}=9$ and $\mathrm{MR}=9$ is occasional). The condition of profit maximization: $\mathbf{M C}=\mathbf{M R}<\mathbf{P}$

For getting the graph solution of the same problem, according to the data of Table 2, we must construct a graph (Fig. 1). It helps to see visually the maximal profit as the maximal deviation of two extreme points $\mathrm{A}$ and $\mathrm{B}$ at the production volume $\mathrm{Q}=9$.

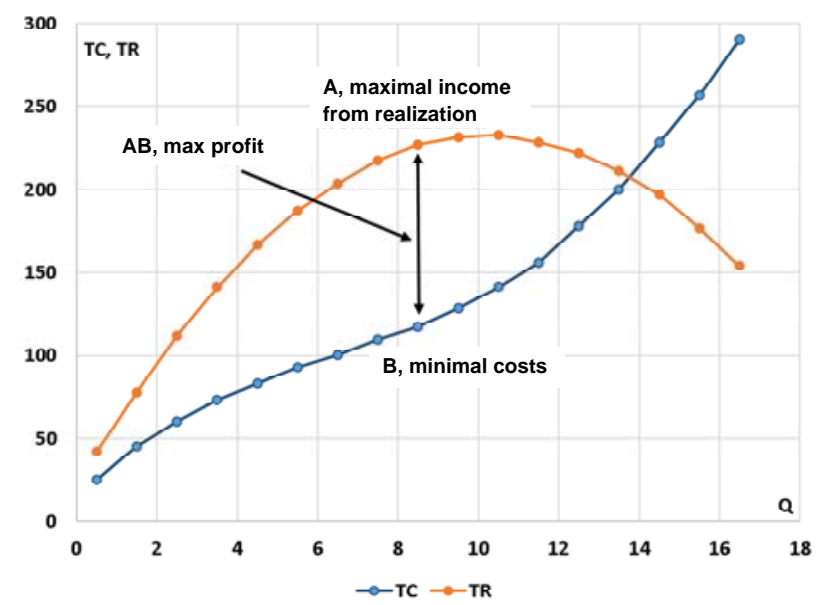

Fig. 1. Maximal profit-making (maximal deviation of the marginal values $\mathrm{MC}$ and $\mathrm{MR}$ )

At making managerial decisions, a manager of external economic activity must use instruments of incremental and marginal analysis.

\section{Conclusions}

1. For today lifelong learning became one of priority directions of social development in all countries. The learning-scientific institute of continuous education of the National aviation university ((LSICE NAU) in Kyiv city works on widening age limits of students of continuous education. Time challenges as migration education became a factor of vector correlation of andragogic training in LSICE NAU. The main cause of it became growing tendencies of youth migration in different countries of the world and, starting from 2014, internal migration of the population from the Donetsk and Lugansk regions in central regions of Ukraine and Kyiv city. In contact with state employment services, LSICE NAU works for preventing and leveling results of labor migration of the population by introducing such forms of staff retraining that provide a worthy employment within the country for temporally replaced persons and unemployed, their social adaptation. Advance learning, oriented on training for postgraduate studies for further activity in the research sphere, becomes today popular as an alternative of labor migration. For solving state problems of staff labor migration, the most successful experience among other training directions is staff retraining by the specialty "External economic activity management" that allows an applicant of this education to be integrated to the world labor market, staying in Ukraine, creating integrating trade units as own business-projects.

2. Under force-majeure conditions in the educational environment, generated by the COVID-19 quarantine, interactive communication by e-correspondence and work in Viber-groups, use of the e-platform ZOOM for distant lectures in online mode became the effective form for students of the "External economic activity management" specialty.

Considering the working experience of LSICE NAU in Kyiv city, we must note that the great positive was a fact that andragogy manifested itself ready for reforming into the extreme working mode: the great arsenal of author presentations, online lectures, e-textbooks was presented to students at the second-third day of the quarantine. But andragogic students turned out to be incapable for processing such volumes of information, whereas it was not extreme for full-time students.

3. As it is demonstrated by the working experience of LSICE NAU in Kyiv city, the common mistake in andragogy is the use of the same working methods for fulltime students and applicants of andragogic education. It would be right to recommend teachers to distinguish working forms for adults and HEI students: the fact that applicants of education for adults and day HEI students are different mental subjects of learning must be taken into account in andragogic work. The theory and methodology of teaching economic disciplines in these two types is quite different. In the case of migration pedagogy, a differential approach to each andragogic student is needed: start from the initial higher education, then retaining for the new format of the labor market within the national economy, taking into account such social-demographic predictors as family status, age of children, age of an applicant, his/her ability to business-risks, material condition and state perks. The training for an interview with an employer is very important that needs from andragogues detail studies at the labor market. Knowledge of the last Incoterms version dominates in employers' requirements in external economic activity management.

As it is demonstrated by the analysis of modern scientific sources, the study of andragogic technologies needs further development, more accent on migration pedagogy, development of such forms of staff training that give a possibility to realize own potential of a specialist in international relations, staying in Ukraine, not migrating within the country: to create centers of international trade, taking into account interests of all countriesparticipants of a project.

4. The obtained results on practical andragogy are useful for practical teachers, andragogues, especially for 
cases of force-majeure circumstances in education for adults, for administrative control over the educational process. According to the working experience of LSICE NAU in Kyiv city, checking the content of ecorrespondence, reaction efficiency of a teacherandragogue to requests of the audience and his/her ability to correct the educational process without losing content volumes of material and disorders as to learning program realization are very effective control over distant activi- ties. The summary e-control as tests, problem solutions, abstracts and so on, must be documented and hold in department archives.

For assessing the quality of migration pedagogy, it is very important to collect information as to employment of continuous education students in the national economy of the country, provided by the system of feedback between the employment service and continuous education applicants.

\section{References}

1. Demograficheskoe starenie. Available at: https://ru.wikipedia.org/wiki/Демографическое_старение

2. Pavlyk, N. P. (2016). Zarubizhnyi dosvid orhanizatsii neformalnoi osvity. Naukovi zapysky. Seriia «Psykholohopedahohichni nauky», 1, 264-273.

3. Hryshyna, T. (2015). Sotsialne zaluchennia liudei starshoho viku: porivnialnyi analiz ukrainskoho ta yevropeiskykh suspilstv. Kyiv, 22.

4. Dubaseniuk, O. A. (Ed.) (2018). Profesiina osvita: andrahohichnyi pidkhid. Zhytomyr: Vyd. O. O. Yevenok, 452.

5. Presner, R. (2016). Formy osvity doroslykh u systemi pisliadyplomnoho navsannia. Zhurnal Aktualni pytannia humanitarnykh nauk, 15, 408-413.

6. Osvita vprodovzh zhyttia: sotsialni zapyty, suchasni vyklyky ta priorytety v realizatsii (2018). Kyiv, 181. $34-40$.

7. Desiatov, T. M. (2015). Intelektualni adaptyvni navchalni systemy doroslykh. Visnyk Cherkaskoho universytetu, 34 (367),

8. Lukianova, L. B. (2015). Akmeolohichnyi resurs andralohichnoi modeli navchannia. Problemy osvity, 84, 31-36.

9. Lukianova, L. B. (2017). Zakonodavche zabezpechennia osvity doroslykh: zarubizhnyi dosvid. Kyiv: Vydavnytstvo TOV" DKS-Tsentr", 147.

10. Lukianova, L. B. (2015). Neperervna osvita vprodovzh zhyttia: istorychnyi ohliad, suchasni realii. Naukovyi visnyk Melitopolskoho derzhavnoho pedahohichnoho universytetu imeni Bohdana Khmelnytskoho. Seriia: Pedahohika, 1 (15), 187-192.

Received date 12.08.2020

Accepted date 17.09.2020

Published date 30.09.2020

Iryna Deineha, $\mathrm{PhD}$, Associated Professor, Director, Educational and Research Institute of Continuing Education, National Aviation University, Liubomyra Huzara ave., 1, Kyiv, Ukraine, 03058

E-mail: dii-osvita@meta.ua

Larysa Hromozdova, PhD, Associate Professor, Department of Regions and Tourism, State Higher Educational Institution «Kyiv National Economic University named after Vadym Hetman», Peremohy ave., 54/1, Kyiv, Ukraine, 03057

E-mail: gromozdovag@gmail.com

Valeriia Kovach, PhD, Deputy Director for Research, Educational and Research Institute of Continuing Education, National Aviation University, Liubomyra Huzara ave., 1, Kyiv, Ukraine, 03058

E-mail: valeriiakovach@gmail.com 